\title{
37. MAGNETOBIOCHRONOLOGY OF LATE CRETACEOUS-PALEOGENE AND LATE CENOZOIC PELAGIC SEDIMENTARY SEQUENCES FROM THE NORTHWEST PACIFIC (DEEP SEA DRILLING PROJECT, LEG 86, SITE 577) ${ }^{1}$
}

\author{
Simonetta Monechi, Scripps Institution of Oceanography \\ Ulrich Bleil, Ruhr-Universität Bochum \\ and \\ Jan Backman, University of Stockholm ${ }^{2}$
}

\begin{abstract}
A synthesis of paleomagnetic and calcareous nannofossil stratigraphies for the sedimentary sequences recovered at Deep Sea Drilling Project (DSDP) Site 577 on the Shatsky Rise is presented. Numerical ages are estimated for a series of nannofossil datum levels from the late Maestrichtian to middle Eocene period ( $\sim 68$ to $\sim 52 \mathrm{~m}$.y. ago) and the late Cenozoic (last $\sim 5 \mathrm{~m} . \mathrm{y}$.). Absolute age control is obtained on the basis of the revised geomagnetic polarity time scale of Berggren et al. (in press).

The results are compared with various sets of data reported in the literature, in particular to magnetobiochronologies derived from marine sections accessible on land in Italy and from recent DSDP boreholes in the South Atlantic, and with the summary by Berggren et al. (in press). Although a number of minor discrepancies remain to be resolved, the remarkable general agreement of the data validates the basic concept of this approach to the elaboration of a calibrated geologic time scale.
\end{abstract}

\section{INTRODUCTION}

At Site 577 on the Shatsky Rise, fairly complete and undisturbed sedimentary sequences of predominantly nannofossil oozes were recovered using the hydraulic piston corer (HPC), in two adjacent holes (Holes 577 and 577A) (Fig. 1). An upper extended late Cenozoic sequence unconformably overlies middle Eocene to Upper Cretaceous sediments (see site chapters, this volume). High resolution stratigraphy of this material was obtained from paleomagnetic and biostratigraphic analyses (Bleil, this volume; Monechi, this volume). On the basis of these results, this study pursues a number of recent research efforts to elaborate numerical ages for biostratigraphic event zonations.

It is well known that standard radiometric methods have only a very limited application to sediments. For this reason, only a few biostratigraphic datum levels have been dated radiometrically. Moreover, as the majority of these measurements have been made on adjacent magmatic rock bodies, among other problems, there is some uncertainty about the exact stratigraphic relationship to the respective sedimentary unit. On the other hand, paleomagnetic analyses have been very successfully applied to pelagic sediments and used to numerically date biostratigraphic zones and datum levels. For the late Neogene, pioneer work in this field was performed on material recovered by conventional piston coring (e.g., Foster and Opdyke, 1970) and by studies of marine sections ex-

\footnotetext{
${ }^{1}$ Heath, G. R., Burckle, L. H., et al., Init. Repts. DSDP, 86: Washington (U.S. Govt. Printing Office).

2 Addresses: (Monechi, present address) Dipartimento di Scienze della Terra, Università di Firenze, Via G. La Pira n.4, 5012\ Firenze, Italy; (Bleil) Institute für Geophysik, Ruhr-Universität Bochum, Postfach 102148, 4630 Bochum, Federal Republic of Germany; (Backman) Department of Geology, University of Stockholm, Stockholm, Sweden.
}

posed on land (e.g., Berggren and Van Couvering, 1974). Theyer and Hammond $(1974 \mathrm{a}, \mathrm{b})$ correlated magnetostratigraphies with radiolarian zonations to about the base of the Neogene from work on a series of equatorial Pacific piston cores. Late Cretaceous (Alvarez et al., 1977) and Paleogene (Lowrie et al., 1982) magnetobiostratigraphies were established from several sections at Gubbio, Italy. To some extent, however, all these studies were subject to specific constraints. In the pelagic environment they are typically restricted to the Neogene period and to lower accumulation rates because of the limited penetration capacity of conventional piston coring. On the other hand, most marine sections accessible on land have been affected to varying degrees by dissolution or diagenesis, casting some doubt on the accuracy of their paleomagnetic and/or biostratigraphic records.

Until recently, rather sparse contributions to this topic came from work on DSDP materials, since rotary drilling frequently results in limited recovery and extensive disturbance of the penetrated sedimentary columns. With the advent of the HPC system, these problems were drastically reduced although not completely solved. The successful operation of this new tool during several DSDP legs in the South Atlantic has provided a wealth of magnetobiochronologic data (Hsü et al., 1984; Berggren et al., in press). For the first time, the Leg 86 HPC material gives the opportunity for a detailed magnetostratigraphic and biostratigraphic study of the Late Cretaceous, the Cretaceous/Tertiary boundary, and much of the Paleogene period on Pacific deep-sea cores.

\section{MAGNETOBIOSTRATIGRAPHY}

From analyses of well preserved calcareous nannofossil assemblages, the positions of the first (FO) and last occurrence (LO) of numerous Cretaceous and $\mathrm{Ce}$ - 


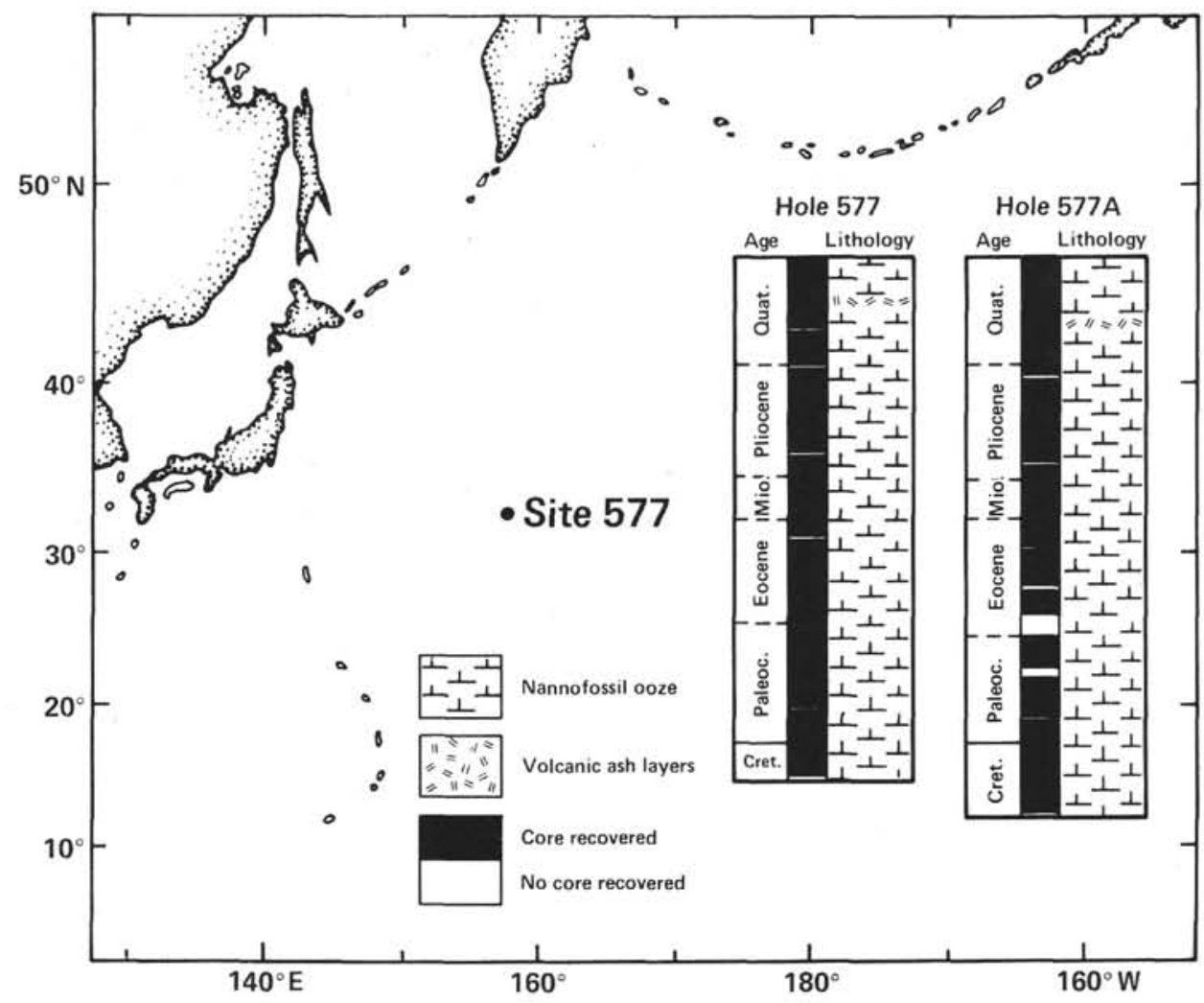

Figure 1. Location of DSDP Site 577 and schematic age, core recovery, and lithostratigraphy of sediments recovered in Holes 577 and 577A using the HPC technique.

nozoic marker events have been recognized in the sedimentary columns recovered at Site 577 in the Northwest Pacific (Monechi, this volume). The coccolith zonation scheme of Bukry (1975) and Okada and Bukry (1980) is used in this chapter.

An almost complete magnetostratigraphy could be established for the entire sequence of Site 577 sediments (Bleil, this volume). The newly revised polarity time scale of Berggren et al. (in press) was used to assign numerical ages to the reversal boundaries. In the late Cenozoic, the series of Earth's magnetic paleofield polarity intervals is specified according to the traditional "epoch" and "event" nomenclature. The pre-Neogene magnetic time units are denoted as "chrons," following the recommendation of the Subcommission on Stratigraphic Classifications (Hedberg et al., 1979). In the terminology developed by Tauxe et al. (1984), a chron extends between the youngest reversal boundaries of a numbered marine magnetic anomaly as defined by Heirtzler et al. (1968) and revised by LaBrecque et al. (1977). The widely used numbering system for the anomaly pattern is thereby incorporated into this magnetostratigraphic time scale and the chron unit distinguished only by prefixing a "C." By its definition, each chron includes not only the time interval of normal polarity corresponding to the respective anomaly number but also the preceding period of reversed polarity (Fig. 2). In order to denote the polarity, the suffix $\mathrm{N}$ (normal) or R (reversed) is added. Further subdivision into subchrons is needed where a chron comprises more than one normal or reversed polarity interval, for example, C-23N-2 indicates the second normal period within Chron 23.

A graphical representation of the magneto- and biostratigraphic results for the Cretaceous and Paleogene is given in Figure 2 and for the late Cenozoic in Figure 3. Using the dates of the Berggren et al. (in press) geomagnetic polarity time scale, numerical ages for the nannofossil datum events were determined by interpolation or extrapolation from the reversal boundaries and are presented in Tables 1 and 2, respectively. The paleomagnetic and biostratigraphic studies did not use the same sample set, except in a few cases. Nevertheless, a sample spacing of on average less than $50 \mathrm{~cm}$ should introduce small inaccuracies as compared to other potential error sources such as incomplete or disturbed recovery and downhole contamination.

We will discuss the individual datum levels starting with the Cretaceous (i.e., proceeding from the base to the top of the holes). The data are compared to the relevant literature. However, as many of these publications are presently available as preprints, it would be inappropriate to go into complicated arguments about specific discrepancies at this stage. Instead, we simply report the actual findings, which are finally summarized in Table 3 .

\section{CRETACEOUS}

From the lowest parts of Holes 577 and 577A, 9.7 and $13.0 \mathrm{~m}$, respectively, of Late Cretaceous sediments were 


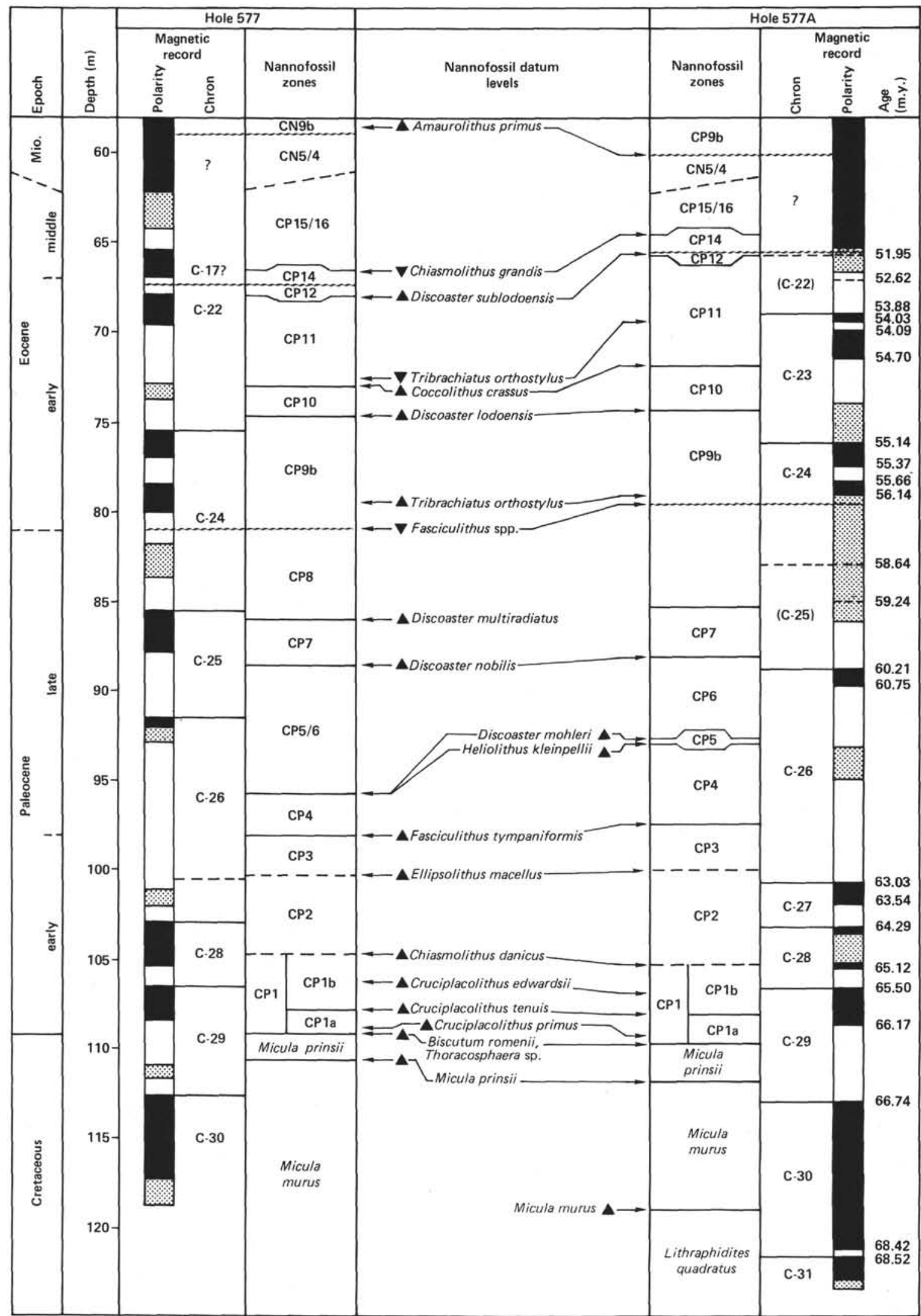

Figure 2. Late Cretaceous-Paleogene nannofossil stratigraphies and magnetostratigraphies in Holes 577 and 577A. Dotted areas in magnetic record refer to gaps in the sample record. The sequence of geomagnetic polarity intervals is defined by the "chron" nomenclature of Tauxe et al. (1984). See caption of Figure 3 for further details. 


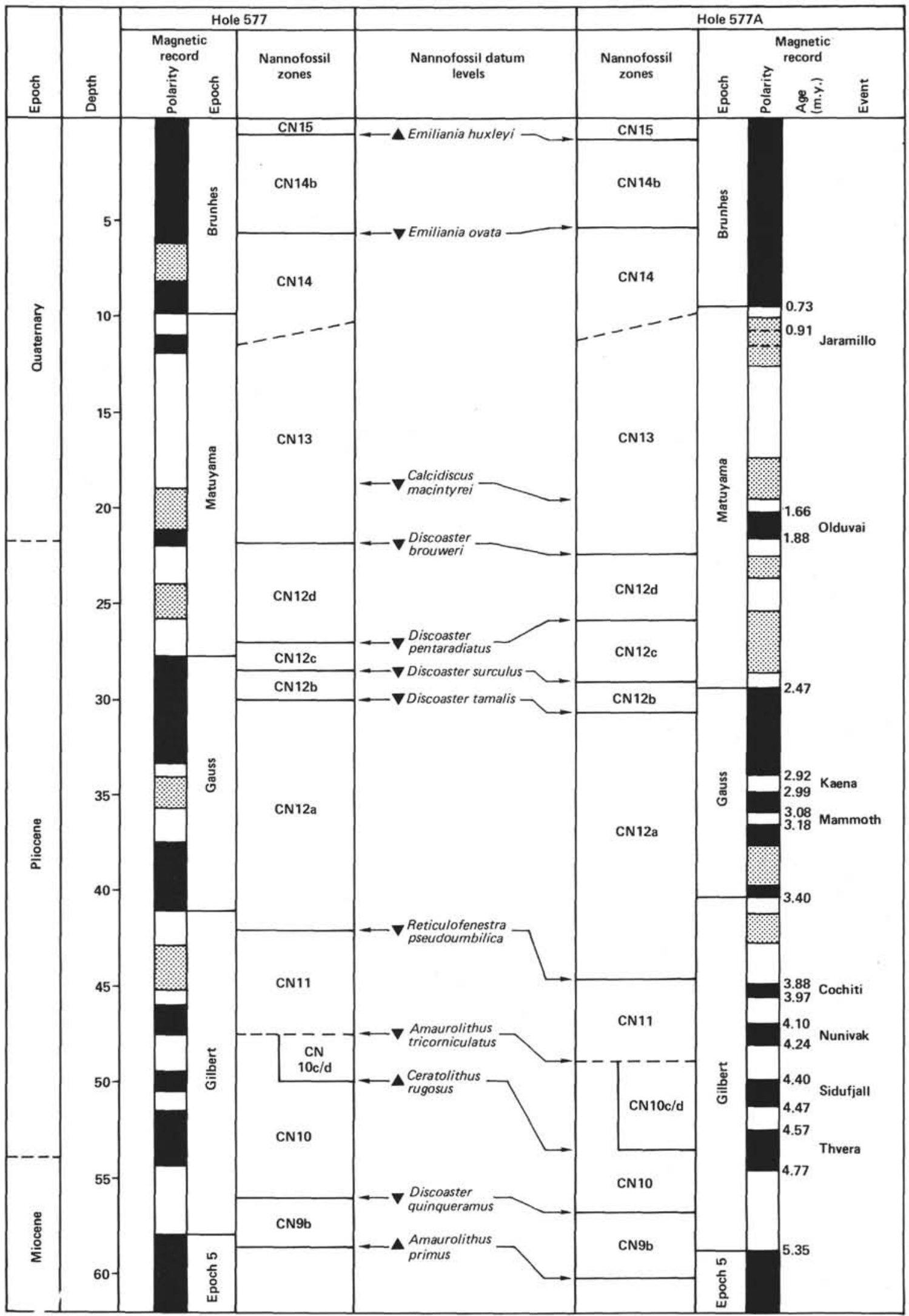

Figure 3. Neogene coccolith stratigraphies and magnetostratigraphies in Holes 577 and 577A. Dotted areas in magnetic record refer to gaps in the sample record. Symbols $\boldsymbol{\Lambda}$ and $\boldsymbol{\nabla}$ denote first and last occurrences; calcareous nannofossil zonations according to Bukry (1975) and Okada and Bukry (1980). Black and white sections indicate normal and reversed polarity intervals of the Earth's paleofield configuration. The nomenclature of McDougall (1977) is used for geomagnetic epochs and events, the polarity time scale of Berggren et al. (in press) to assign numerical ages to reversal boundaries. See text for a discussion of alternative interpretations of geomagnetic reversal sequence. 
Table 1A. Numerical ages of Paleogene nannofossil events as inferred from the magnetostratigraphic record in Hole 577.

\begin{tabular}{|c|c|c|c|c|c|c|}
\hline \multicolumn{3}{|r|}{ Nannofossil } & \multirow{2}{*}{$\begin{array}{l}\text { Sub-bottom } \\
\text { depth } \\
\text { (m) }\end{array}$} & \multirow[b]{2}{*}{ Chron } & \multirow{2}{*}{$\begin{array}{c}\text { Age } \\
\text { (m.y.) }\end{array}$} & \multirow{2}{*}{$\begin{array}{l}\text { Time } \\
\text { basis }^{\mathbf{a}}\end{array}$} \\
\hline Zone & & Event & & & & \\
\hline \multirow{2}{*}{$\mathrm{CP} 12$} & FO & Discoaster sublodoensis & 68.00 & $C-22 \mathrm{~N}$ & 51.97 & $\mathrm{C}-22 \mathrm{~N}$ \\
\hline & LO & Tribrachiatus orthostylus & 72.50 & $?$ & $(53.98)$ & $C-22 \mathrm{~N}$ \\
\hline CP11 & FO & Coccolithus crassus & 72.91 & $?$ & (54.17) & $C-22 \mathrm{~N}$ \\
\hline \multirow[t]{2}{*}{ CP10 } & FO & Discoaster lodoensis & 74.60 & C-23R-2 & 55.01 & $C-24 N-1$ \\
\hline & FO & Tribrachiatus orthostylus & 79.40 & C- $24 \mathrm{~N}-2$ & 55.96 & $C-24 \mathrm{~N}-2$ \\
\hline CP8 & FO & Discoaster multiradiatus & 86.00 & $C-25 \mathrm{~N}$ & 58.79 & $C-25 \mathrm{~N}$ \\
\hline CP7 & FO & Discoaster nobilis & 88.50 & $C-25 R$ & 59.46 & $C-25 R$ \\
\hline CP4 & FO & Fasciculithus tympaniformis & 98.00 & $C-26 R$ & (62.58) & $C-28$ \\
\hline CP3 & FO & Ellipsolithus macellus & 100.20 & $C-26 \mathrm{R}$ & (63.34) & C-28 \\
\hline CP2 & FO & Chiasmolithus danicus s.s. & 104.66 & $\mathrm{C}-28 \mathrm{~N}$ & 64.91 & $C-28 \mathrm{~N}$ \\
\hline CPIb & FO & Cruciplacolithus edwardsii & 106.22 & $C-28 R$ & 65.43 & $C-28 R$ \\
\hline \multirow[t]{5}{*}{ CP1b } & FO & Cruciplacolithus temuis & 107.86 & C- $29 \mathrm{~N}$ & 66.00 & C-29N \\
\hline & FO & Cruciplacolithus primus & 108.80 & C-29R & 66.23 & C-29R \\
\hline & Cret: & eous/Tertiary boundary & 109.10 & C-29R & 66.43 & $\mathrm{C}-29 \mathrm{~N}$ \\
\hline & & & & $C-29 R$ & 66.27 & $C-29 R$ \\
\hline & FO & Micula prinsii & 110.72 & C-29R & 66.50 & C-29R \\
\hline
\end{tabular}

Note: Parentheses in age column indicate reduced quality of data.

a Magnetostratigraphic data by Bleil (this volume) using the geomagnetic polarity time scale of Berggren et al. (in press).

Table 1B. Numerical ages of Paleogene nannofossil events as inferred from the magnetostratigraphic record in Hole 577A.

\begin{tabular}{|c|c|c|c|c|c|c|}
\hline \multicolumn{3}{|r|}{ Nannofossil } & \multirow{2}{*}{$\begin{array}{l}\text { Sub-bottom } \\
\text { depth } \\
\text { (m) }\end{array}$} & \multirow[b]{2}{*}{ Chron } & \multirow{2}{*}{$\begin{array}{l}\text { Age } \\
\text { (m.y.) }\end{array}$} & \multirow{2}{*}{$\begin{array}{c}\text { Time } \\
\text { basis }^{\mathrm{a}}\end{array}$} \\
\hline Zone & & Event & & & & \\
\hline & LO & Tribrachiatus orthostylus & 69.80 & C-23R-1 & 54.06 & C-23R-1 \\
\hline CP11 & FO & Coccolithus crassus & 71.95 & C-23R-2 & 54.86 & C-23R-2 \\
\hline \multirow{2}{*}{ CP10 } & FO & Discoaster lodoensis & 74.43 & (C-23R-2) & $(55.02)$ & C23R-2/C-24N-1 \\
\hline & FO & Tribrachiatus orthostylus & 79.20 & (C-24N-2) & $(55.90)$ & C-24R-1 \\
\hline CP7 & FO & Discoaster nobilis & 88.10 & C-25R & 59.72 & C $-26 \mathrm{~N}$ \\
\hline CP6 & FO & Discoaster mohleri & 92.78 & $C-26 R$ & 61.12 & C-26 \\
\hline CP5 & FO & Heliolithus kleinpellii & 93.00 & C-26R & 61.17 & C. 26 \\
\hline CP4 & FO & Fasciculithus tympaniformis & 97.50 & C-26R & 62.22 & C-26 \\
\hline $\mathrm{CP} 3$ & FO & Ellipsolithus macellus & 99.80 & C-26R & 62.76 & C.26 \\
\hline $\mathrm{CP} 2$ & FO & Chiasmolithus danicus s.s. & 105.35 & C $-28 \mathrm{~N}$ & 65.08 & C- $28 \mathrm{~N}$ \\
\hline CPIb & FO & Cruciplacolithus edwardsii & 106.96 & C- $-29 \mathrm{~N}$ & 65.57 & $\mathrm{C}-29 \mathrm{~N}$ \\
\hline \multirow[t]{7}{*}{ CPIb } & FO & Cruciplacolithus tenuis & 108.06 & C- $29 \mathrm{~N}$ & 65.96 & C- $-29 \mathrm{~N}$ \\
\hline & FO & Cruciplacolithus primus & 109.31 & C- $29 \mathrm{R}$ & 66.25 & C-29R \\
\hline & \multirow{3}{*}{\multicolumn{2}{|c|}{ Cretaceous/Tertiary boundary }} & 109.62 & C- $29 \mathrm{R}$ & 66.51 & C- $-29 \mathrm{~N}$ \\
\hline & & & & & 66.29 & C-29R \\
\hline & & & & & $(66.02)$ & C- -30 \\
\hline & FO & Micula prinsii & 111.86 & C-29R & 66.58 & C-29R \\
\hline & FO & Micula murus & 120.34 & C- $-30 \mathrm{~N}$ & 68.25 & C-30 \\
\hline
\end{tabular}

Note: Parentheses in age column indicate reduced quality of data.

${ }^{a}$ Magnetostratigraphic data by Bleil (this volume) using the geomagnetic polarity time scale of Berggren et al. (in press).

recovered. According to the calcareous nannofossil and planktonic foraminifer stratigraphies, these sediments belong to the Maestrichtian Stage.

Hole 577 ends at $118.80 \mathrm{~m}$ below seafloor in the nannofossil Micula murus zone within the magnetic Subchron C-30N. At its base, therefore, an age of less than $68.42 \mathrm{~m} . \mathrm{y}$. is attained. The C-30/C-29 reversal boundary $(66.74 \mathrm{~m} . \mathrm{y}$. ago $)$ occurs at $112.60 \mathrm{~m}$.

The lowest magnetic reversal in Hole 577A is recognized at $121.65 \mathrm{~m}$ sub-bottom and identified as the C-31/C-30 boundary ( $68.52 \mathrm{~m} . \mathrm{y}$. ago). This also gives a minimum age for the base of the hole at $123.40 \mathrm{~m}$. The C-30R/C-30N (121.18 m; 68.42 m.y. ago) and C-30/ C-29 (113.09 m; $66.74 \mathrm{~m} . \mathrm{y}$. ago) boundaries allow the interpolation of a numerical age of $68.25 \mathrm{~m}$.y. for the
FO of M. murus $(120.34 \mathrm{~m})$ assuming a constant sedimentation rate of $4.82 \mathrm{~m} / \mathrm{m}$.y. in the interval between these two dates. In general, the youngest Cretaceous calcareous nannofossil assemblage characterized by the presence of $M$. murus appears about $1 \mathrm{~m}$.y. before the beginning of the Tertiary (Thierstein, 1982). The best estimate for this time span from the present data would be about 1.5 m.y. Similar to the present result, Monechi and Thierstein (in press) have recognized the M. murus zonal boundary in the lower part of C-30N in the Bottaccione section near Gubbio, Italy. At DSDP sites in the South Atlantic it was found either in slightly lower (near the C-30N/C-30R boundary: Leg 73, Hsü et al., 1984) or in higher levels (mid C-30N: Leg 74, Shackleton et al., 1984). 
Table 2A. Numerical ages of Neogene nannofossil events as inferred from the magnetostratigraphic record in Hole 577.

\begin{tabular}{|c|c|c|c|c|c|c|c|}
\hline \multicolumn{3}{|r|}{ Nannofossil } & \multirow{2}{*}{$\begin{array}{l}\text { Sub-bottom } \\
\text { depth } \\
\text { (m) }\end{array}$} & \multicolumn{2}{|c|}{$\begin{array}{l}\text { Magnetostratigraphic } \\
\text { position of event }\end{array}$} & \multirow{2}{*}{$\begin{array}{c}\text { Age } \\
\text { (m.y.) }\end{array}$} & \multirow{2}{*}{$\begin{array}{l}\text { Time } \\
\text { basis }^{\mathrm{a}}\end{array}$} \\
\hline Zone & & Event & & Epoch & Level & & \\
\hline $\mathrm{CN} 15$ & FO & Emiliania huxleyi & 0.50 & Brunhes & Late Brunhes & $(0.04)$ & Brunhes \\
\hline \multirow[t]{2}{*}{$\mathrm{CN} 14 \mathrm{~b}$} & LO & Emiliania ovata & 5.75 & Brunhes & Mid-Brunhes & $(0.43)$ & Brunhes \\
\hline & LO & Calcidiscus macintyrei & 18.66 & Matuyama & Mid-Matuyama & 1.59 & $\begin{array}{l}\text { Base of Jaramillo-base of } \\
\text { Olduvai }\end{array}$ \\
\hline $\mathrm{CN} 13$ & LO & Discoaster brouweri & 21.76 & Matuyama & Base of Olduvai & 1.86 & $\begin{array}{l}\text { Base of Olduvai-Matuyama/ } \\
\text { Gauss boundary }\end{array}$ \\
\hline $\mathrm{CN} 12 \mathrm{~d}$ & LO & Discoaster pentaradiatus & 26.92 & Matuyama & $\begin{array}{l}\text { Near Matuyama/Gauss } \\
\text { boundary }\end{array}$ & 2.39 & $\begin{array}{l}\text { Base of Olduvai-Matuyama/ } \\
\text { Gauss boundary }\end{array}$ \\
\hline $\mathrm{CN} 12 \mathrm{c}$ & LO & Discoaster surculus & 28.42 & Gauss & $\begin{array}{l}\text { Near Matuyama/Gauss } \\
\text { boundary }\end{array}$ & 2.53 & $\begin{array}{l}\text { Matuyama/Gauss bound- } \\
\text { ary-top of Kaena }\end{array}$ \\
\hline $\mathrm{CN} 12 \mathrm{~b}$ & LO & Discoaster tamalis & 29.92 & Gauss & Late Gauss & 2.65 & $\begin{array}{l}\text { Matuyama/Gauss bound- } \\
\text { ary-top of Kaena }\end{array}$ \\
\hline $\mathrm{CN} 12 \mathrm{a}$ & LO & Reticulofenestra pseudoumbilica & 42.00 & Gilbert & $\begin{array}{l}\text { Near Gauss/Gilbert } \\
\text { boundary }\end{array}$ & 3.55 & $\begin{array}{l}\text { Gauss/Gilbert boundary-top } \\
\text { of Nunivak }\end{array}$ \\
\hline CN11 & LO & Amaurolithus tricorniculatus & 47.50 & Gilbert & Just below Nunivak & 4.24 & $\begin{array}{l}\text { Base of Nunivak-top of } \\
\text { Sidufjall }\end{array}$ \\
\hline $\mathrm{CN} 10 \mathrm{c}$ & FO & Ceratolithus rugosus & 49.90 & Gilbert & Mid-Sidufjall & 4.43 & Sidufjall \\
\hline $\mathrm{CN} 10$ & LO & Discoaster quinqueramus & 56.00 & Gilbert & Early Gilbert & 5.04 & $\begin{array}{l}\text { Base of Thvera-Gilbert/ } \\
\text { Epoch } 5 \text { boundary }\end{array}$ \\
\hline $\mathrm{CN} 9 \mathrm{~b}$ & FO & Amaurolithus primus & 58.60 & Epoch 5 & $\begin{array}{l}\text { Near Gilbert/Epoch } 5 \\
\text { boundary }\end{array}$ & 5.45 & $\begin{array}{l}\text { Base of Thvera-Gilbert/ } \\
\text { Epoch } 5 \text { boundary }\end{array}$ \\
\hline
\end{tabular}

Note: Parentheses in age column indicate reduced quality of data.

${ }^{a}$ Magnetostratigraphic data by Bleil (this volume) using the geomagnetic polarity time scale of Berggren et al. (in press).

Table 2B. Numerical ages of Neogene nannofossil events as inferred from the magnetostratigraphic record in Hole 577A.

\begin{tabular}{|c|c|c|c|c|c|c|c|}
\hline \multicolumn{3}{|r|}{ Nannofossil } & \multirow{2}{*}{$\begin{array}{l}\text { Sub-bottom } \\
\text { depth } \\
\text { (m) }\end{array}$} & \multicolumn{2}{|c|}{$\begin{array}{l}\text { Magnetostratigraphic } \\
\text { position of event }\end{array}$} & \multirow{2}{*}{$\begin{array}{c}\text { Age } \\
\text { (m.y.) }\end{array}$} & \multirow{2}{*}{$\begin{array}{l}\text { Time } \\
\text { basis }^{\mathrm{a}}\end{array}$} \\
\hline Zone & & Event & & Epoch & Level & & \\
\hline $\mathrm{CN} 15$ & FO & Emiliania huxleyi & 1.00 & Brunhes & Late Brunhes & $(0.07)$ & Brunhes \\
\hline \multirow[t]{2}{*}{ CN14b } & LO & Emiliania ovata & 5.50 & Brunhes & Mid-Brunhes & $(0.41)$ & Brunhes \\
\hline & LO & Calcidiscus macintyrei & 19.50 & Matuyama & Mid-Matuyama & 1.58 & $\begin{array}{l}\text { Brunhes/Matuyama bound- } \\
\text { ary-top of Olduvai }\end{array}$ \\
\hline CN13 & LO & Discoaster brouweri & 22.50 & Matuyama & Just below Olduvai & 1.94 & $\begin{array}{l}\text { Base of Olduvai-Matuyama/ } \\
\text { Gauss boundary }\end{array}$ \\
\hline $\mathrm{CN} 12 \mathrm{~d}$ & LO & Discoaster pentaradiatus & 25.90 & Matuyama & Early Matuyama & 2.20 & $\begin{array}{l}\text { Base of Olduvai-Matuyama/ } \\
\text { Gauss boundary }\end{array}$ \\
\hline $\mathrm{CN} 12 \mathrm{c}$ & LO & Discoaster surculus & 29.20 & Matuyama & $\begin{array}{l}\text { Near Matuyama/Gauss } \\
\text { boundary }\end{array}$ & 2.45 & $\begin{array}{l}\text { Base of Olduvai-Matuyama/ } \\
\text { Gauss boundary }\end{array}$ \\
\hline $\mathrm{CN} 12 \mathrm{~b}$ & LO & Discoaster tamalis & 30.70 & Gauss & $\begin{array}{l}\text { Near Matuyama/Gauss } \\
\text { boundary }\end{array}$ & 2.59 & $\begin{array}{l}\text { Matuyama/Gauss bound- } \\
\text { ary-top of Kaena }\end{array}$ \\
\hline $\mathrm{CN} 12 \mathrm{a}$ & LO & Reticulofenestra pseudoumbilica & 44.90 & Gilbert & Just above Cochiti & 3.87 & $\begin{array}{l}\text { Gauss/Gilbert boundary-top } \\
\text { of Cochiti }\end{array}$ \\
\hline CN11 & LO & Amaurolithus tricorniculatus & 49.05 & Gilbert & $\begin{array}{l}\text { Between Nunivak and } \\
\text { Sidufjall }\end{array}$ & 4.32 & $\begin{array}{l}\text { Base of Nunivak-top of } \\
\text { Sidufjall }\end{array}$ \\
\hline CN10c & FO & Ceratolithus rugosus & 53.55 & Gilbert & Mid-Thvera & 4.67 & Thvera \\
\hline $\mathrm{CN} 10$ & LO & Discoaster quinqueramus & 56.90 & Gilbert & Early Gilbert & 5.09 & $\begin{array}{l}\text { Base of Thvera-Gilbert/ } \\
\text { Epoch } 5 \text { boundary }\end{array}$ \\
\hline $\mathrm{CN} 9 \mathrm{~b}$ & FO & Amaurolithus primus & 60.26 & Epoch 5 & Late Epoch 5 & 5.54 & $\begin{array}{l}\text { Base of Thvera-Gilbert/ } \\
\text { Epoch } 5 \text { boundary }\end{array}$ \\
\hline
\end{tabular}

${ }^{\text {a }}$ Magnetostratigraphic data by Bleil (this volume) using the geomagnetic polarity time scale of Berggren et al. (in press).

\section{CRETACEOUS/TERTIARY BOUNDARY}

Based on biostratigraphic evidence, the Cretaceous/ Tertiary boundary was identified at 109.10 and $109.62 \mathrm{~m}$ depth below seafloor in Holes 577 and 577A, respectively. It is characterized by an abrupt extinction of Mesozoic forms of marine microfauna and microflora, the first appearance of several Tertiary nannofossil taxa (Biscutum romeinii, Thoracosphaera, Cyclagelosphaera), and the FO of Globigerina eugubina. Details of the calcareous nannofossil stratigraphy are presented in a separate chapter (Monechi, this volume).
In both holes the boundary is located within the interval of reversed magnetic polarity that separates marine magnetic Anomalies 29 and 30, denoted as the C-29R subchron in the presently used nomenclature (Tauxe et al., 1984). Worldwide, the same result was obtained from analyses of various marine sections (Alvarez et al., 1977; Alvarez and Lowrie, 1978; Hsü et al., 1982; Shackleton et al., 1984; Monechi and Thierstein, in press; Thierstein, 1982, and references therein). However, these findings conflict with interpretations of biostratigraphic and magnetostratigraphic studies of the Cretaceous/Tertiary boundary in continental sections (Butler et al., 1977; 
Table 3. Late Cretaceous to Eocene numerical ages of nannofossil datum levels for Leg 86 , Site 577 as compared to age estimates for Leg 74 (Shackleton et al., 1984), a summary by Berggren et al. (in press) using data from South Atlantic Legs 72-74 and results from marine sections in Italy. ${ }^{\text {a }}$

\begin{tabular}{lcccc}
\hline & \multicolumn{1}{c}{ Datum } & $\begin{array}{c}\text { This chapter } \\
\text { (best estimates) }\end{array}$ & $\begin{array}{c}\text { Shackleton } \\
\text { et al. }\end{array}$ & $\begin{array}{c}\text { Berggren } \\
\text { et al. }\end{array}$ \\
\hline FO Micula murus & 68.3 & 67.5 & - \\
Cretaceous/Tertiary boundary & $66.3-66.5$ & 66.46 & - \\
FO Cruciplacolithus primus & 66.2 & 66.1 & - \\
FO Cruciplacolithus tenuis & 66.0 & 65.9 & 65.9 \\
FO Cruciplacolithus danicus & 65.0 & 64.9 & 64.8 \\
FO Ellipsolithus macellus & 62.8 & 63.0 & 62.9 \\
FO Fasciculithus tympaniformis & 62.2 & 62.0 & 62.6 \\
FO Heliolithus kleinpellii & 61.2 & 61.6 & 61.6 \\
FO Discoaster mohleri & 61.1 & 60.5 & 60.4 \\
FO Discoaster multiradiatus & 58.8 & 59.0 & 59.2 \\
LO Fasciculithus spp. & 57.2 & 57.6 & 57.4 \\
FO Tribrachiatus contortus & 56.3 & 56.8 & - \\
LO Tribrachiatus contortus & 56.0 & 56.3 & - \\
FO Tribrachiatus orthostylus & 55.9 & 56.3 & 56.5 \\
FO Discoaster lodoensis & 55.0 & 55.4 & 55.3 \\
LO Tribrachiatus orthostylus & 54.1 & 54.0 & 54.4 \\
LO Discoaster sublodoensis & 52.0 & 51.7 & - \\
\hline
\end{tabular}

a All ages listed are determined by interpolation from magnetostratigraphies on the basis of the revised geomagnetic polarity time scale of Berggren et al. (in press).

Lindsay et al., 1981). A detailed discussion of this problem is given by Berggren et al. (in press).

As pointed out by Thierstein (1982), the relative position of the paleontological boundary within the magnetic C-29R subchron is highly variable in different pelagic sequences, indicating major changes in sedimentation rates and/or the possible presence of hiatuses. Similar to the situation in most of these sections, the C-29R subchron is expanded in the sedimentary columns recovered at Site 577 relative to the preceding $\mathrm{C}-30 \mathrm{~N}$ and the following C-29N normal polarity subchron. Irrespective of potential inaccuracies resulting from a variable or even discontinuous accumulation at the Cretaceous/Tertiary boundary, a numerical age has been determined for this horizon both by interpolating linearly from the magnetic C-29R boundaries and extrapolating downward using the C-29N boundaries and upward using C-30N (Table 1). The latter calculation was only possible in Hole 577A and yielded an obviously irrelevant datum. The other estimates vary from about 66.3 to $66.5 \mathrm{~m}$.y., in complete agreement with other recent evaluations based on the same time scale (Shackleton et al., 1984).

\section{PALEOGENE}

In both holes the $\mathrm{FO}$ of Cruciplacolithus tenuis (CP1b zonal boundary) falls within the magnetic C-29N subchron; an identical position was found in the South Atlantic DSDP drill holes (Hsü et al,. 1984; Shackleton et al., 1984). The FO of C. edwardsii is recorded in the upper part of the same geomagnetic interval in Hole 577, whereas in Hole $577 \mathrm{~A}$ it is located just above the C-29N/ C-28R reversal boundary. The $C$. edwardsii form, characterized by a slightly tilted central cross, has been incorporated here into the Chiasmolithus danicus species (Monechi, 1977; Monechi and Thierstein, in press). The FO of $C$. danicus s.s. (Zone CP2) as described by Romein (1979) occurs in the lower part of C-28N in both holes. Again, this agrees with results from the South Atlantic.

The C-27N subchron (marine magnetic Anomaly 27) could only be recognized in the sedimentary column recovered from Hole 577A. In the Hole 577 sequence this interval was presumably lost in between Cores 11 and 12. Furthermore, in places the Core 11 sediments of this hole showed an atypical degree of drilling disturbance. Severe downhole contamination was observed in some intervals, therefore, the nannofossil datum levels and their position relative to magnetostratigraphic boundaries may be of reduced quality here. In the C-26R subchron a series of four marker events was identified in both holes (Fig. 2): FO of Ellipsolithus macellus (Zone CP3), FO of Fasciculithus tympaniformis (Zone CP4), FO of Heliolithus kleinpellii (Zone CP5), and FO of Discoaster mohleri (Zone CP6).

E. macellus shows a discontinuous presence in Zones $\mathrm{CP} 3$ and CP4. In both the Bottaccione and Contessa profiles near Gubbio, Italy, where this zonal marker is also very rare, its FO was found deeper in the C-28R subchron. This discrepancy is likely to reflect preservational or environmental problems. As in the present case, in the South Atlantic the first appearance level of $E$. macellus was consistently recorded just above the C-27N/ $\mathrm{C}-26 \mathrm{R}$ reversal boundary (Berggren et al., in press). These results indicate that the FO of $E$. macellus represents an inaccurate datum event. The FO of $F$. tympaniformis in the lower half of the C-26R subchron coincides reasonably well with all available results from Italy and the South Atlantic.

According to the South Atlantic data summarized by Berggren et al. (in press), the nannofossil Zone CP5 should span about 1.2 m.y. At Site 577 this interval appears to be very compressed. In fact, downhole contamination prevents any detailed conclusions about its stratigraphic distribution. In Hole 577A the FO levels of $H$. kleinpellii and D. mohleri are observed in the upper half of C-26R. They are separated by a little more than $20 \mathrm{~cm}$ and could be distinguished only on the basis of a very dense sampling around this horizon. In Hole 577 the FO of the two species could not be discriminated.

The lowest occurrence of $H$. kleinpellii in the Contessa and Bottaccione sections is within one of several normal magnetic polarity intervals, which have all been correlated with the marine magnetic Anomaly 26 . However, from Leg 74 analyses, Shackleton et al. (1984) have reported a position in the mid C-26R subchron in agreement with the present result. The FO of $D$. mohleri was recorded within the C-26N subchron in the Gubbio sections and in the Leg 74 material, but in the South Atlantic also below the C-26N/C-26R boundary (Legs 72 and 73 , see summary by Berggren et al., in press), as now in the Northwest Pacific (Fig. 2).

The FO of Discoaster nobilis (Zone CP7) is found in the upper half of the C-25R subchron in Hole 577, in agreement with this datum level in the Contessa profile (Monechi and Thierstein, in press). In Hole 577A it has a position closer to the C-26N/C-26R boundary. The FO of Discoaster multiradiatus (Zone CP8) falls within the $\mathrm{C}-25 \mathrm{~N}$ subchron (marine magnetic Anomaly 25) in 
Hole 577. As Core 9 of Hole 577A has a recovery of only $3.80 \mathrm{~m}$ (or $40 \%$ ) and since the sediments are badly disturbed, we could not identify either the base of the $\mathrm{CP} 8$ zone or the C-25N subchron. In all available reports, the base of the CP8 zonal boundary has been found within the C-25N subchron, although there exist some discrepancies as to its exact position within this period of normal polarity.

The LO of Fasciculithus that was recorded in the C-24R-2 subchron in the Hole 577 sediments (Core 9/10 transition) agrees with observations in the South Atlantic (Leg 74, Shackleton et al., 1984) and in the Contessa section (Lowrie et al., 1982). This marker level was frequently thought to coincide with the $\mathrm{CP} 8 / \mathrm{CP} 9$ nannofossil zonal boundary and therefore to represent the Paleocene/Eocene boundary. However, according to Shackleton et al. (1984), the LO of Fasciculithus occurs stratigraphically lower (within Zone CP8) than the FO of Discoaster diastypus (top of Zone CP8). In Hole 577 the FO of Tribrachiatus nunnii/Tribrachiatus contortus occurs shortly above the LO of Fasciculithus, thus corroborating the results of Shackleton et al. (1984). The stratigraphic position for the Paleocene/Eocene boundary between marine magnetic Anomalies 24 and 25 (C-24R-2 subchron) indicated here is the same as in all other analyzed pelagic sections.

The FO of Tribrachiatus orthostylus is located in the lower part of the geomagnetic C-24N-2 subchron in Hole 577 . The previously mentioned lack of recovery in Core 9 prevented us from successfully correlating its position with the magnetostratigraphic record in Hole 577A. Compared with data from the South Atlantic (DSDP Legs 72 and 73) and Italy (Lowrie et al., 1982; Monechi and Thierstein, in press), the datum level in Hole 577 appears to lie slightly too high since the FO of $T$. orthostylus in the South Atlantic and Italy was always found just below the C-24N-2/C-24R-2 reversal boundary.

The FO of Discoaster lodoensis (Zone CP10) is recorded in the reversed magnetic interval following Anomaly 24 (C-23R-2 subchron) in both holes at Site 577. This datum level has been described as occurring in about the same stratigraphic horizon in the Contessa section at Gubbio (Monechi and Thierstein, in press) and in the South Atlantic (Shackleton et al., 1984). According to other reports, however, the FO of D. lodoensis is already found in the C-24N-1 subchron (see review by Berggren et al., in press).

The identification of the geomagnetic C-24 chron in the Site 577 sediments is strongly supported by carbon isotope stratigraphy results (Shackleton, this volume). These data further indicate a "hiatus" between Cores 8 and 9 in Hole 577. In fact, a very detailed correlation of the two holes suggests that about $2.6 \mathrm{~m}$ of sediments have not been recovered at this level in Hole 577 (see below and Fig. 4).

The base of the nannofossil Zone CP11, as defined by the FO of Coccolithus crassus, is situated in the magnetic C-23R-2 subchron in Hole 577A, but was recorded at different levels in normal polarity intervals related to the marine magnetic Anomaly 23 in the Gubbio sections (Monechi and Thierstein, in press). Apparently some dis-

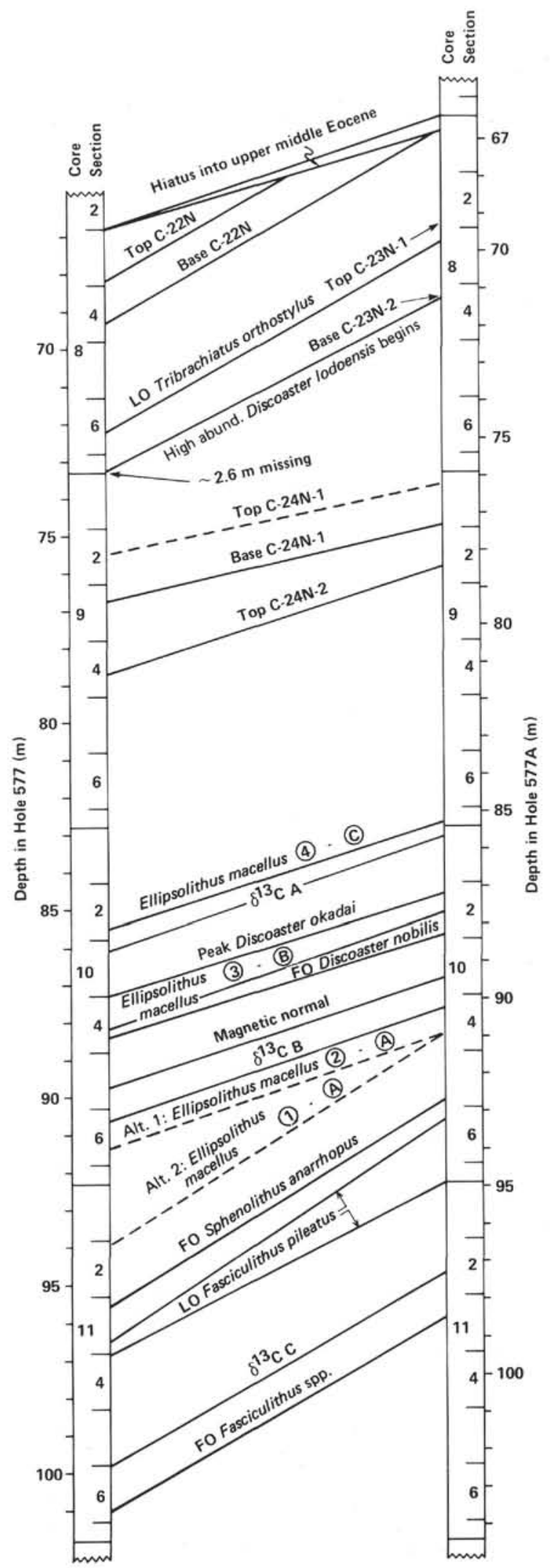

Figure 4. Detailed correlations of nannofossil data, geomagnetic reversal boundaries, and carbon isotope data (Shackleton, this volume) in Cores 8 through 11 of Holes 577 and 577A allowing quantification of apparent gaps in core recovery (see text for details). 
crepancies also exist regarding the $\mathrm{LO}$ of $T$. orthostylus. In Hole 577A this species disappears within the C-23R-1 magnetic subchron, in agreement with results from Leg 74 (Shackleton et al., 1984). Lowrie et al. (1982) reported this datum event in the C-23N-2 subchron in the Contessa section at Gubbio. However, in the same profile Monechi and Thierstein (in press) report a $\mathrm{LO}$ for $T$. orthostylus shortly after the C-23/C-22 reversal boundary. The reason for this difference is not known.

The C-22N subchron could only be recognized in Hole 577 and was identified on the basis of the FO of Discoaster sublodoensis (base of CP12 zonal boundary), which was reported at this level in the Contessa section in Gubbio (Monechi and Thierstein, in press) and in the South Atlantic (Shackleton et al., 1984).

A hiatus is observed at around $65 \mathrm{~m}$ sub-bottom between the CP12 and CP14 nannofossil zones, and a major unconformity separates middle Eocene from late Miocene sediments at around $60 \mathrm{~m}$ below seafloor in both holes. Paleomagnetic analyses in this interval yielded no useful results. The correlation of a normal polarity section in Hole 577 to the marine magnetic Anomaly 17 (Fig. 2), therefore, is tentative and only justified because Hsü et al. (1984) have recognized the LO of Chiasmolithus grandis in this magnetostratigraphic position in the South Atlantic. In the different Gubbio sections, the $\mathrm{LO}$ of $C$. grandis is located within marine magnetic Anomaly 18 (Monechi and Thierstein, in press).

One of us (JB) has made a quantitative nannofossil study of Cores 8 through 11 from Holes 577 and 577A, results which will be presented elsewhere. Nevertheless, we consider it worthwhile to show the resulting correlations between the two holes (Fig. 4). Compared with the present results, the only discrepancies in positions of datum levels are those caused by different sample spacing, implying that consistent taxonomic concepts were applied.

If perfect recoveries had been achieved from the two holes, one would expect, by assuming an identical depositional history, the complete set of correlations of bio-, magneto-, and stable isotope stratigraphy indications to become displayed as parallel lines. Figure 4A shows that lines of correlation are in fact parallel, but also reveals two levels showing imperfect recovery or disturbance. The first occurs between Cores 8 and 9 in Hole 577, where $2.6 \mathrm{~m}$ of sediment is missing as indicated by the shift in relative abundance of $D$. lodoensis (J. Backman, unpublished observations).

In Hole 577, the relative abundance of $D$. lodoensis increases by a factor of two between Cores 8 and 9 . The corresponding increase in Hole 577A occurs at the base of the C-23N-2 subchron. Referring to this level in the two holes and that indicated by the top of C-24N-1, it becomes obvious that Hole 577 suffers a loss of material in the pertinent interval, presumably at the core boundary. This observation provides a plausible explanation as to why the $\mathrm{C}-23 \mathrm{~N}$ subchrons were not identified in Hole 577.

The second level of imperfect recovery or disturbance occurs at the transition between Cores 10 and 11 in Hole 577, which correlates to mid-Core 10 in Hole 577A. Abun- dance plots of $E$. macellus are of particular importance for the latter problem (Fig. 5). Figure 5 shows that there are two ways of correlating the two holes: alternative one suggests that the uppermost part of Core 11 in Hole 577 is recored, and alternative two suggests that approximately $2.7 \mathrm{~m}$ of sediment is missing in mid-Core 10 in Hole 577A. We do not possess any definitive evidence regarding which of these alternatives is the valid one (see also discussion by Shackleton, this volume). This study emphasizes, on one hand, the importance of repeated coring of important sections, evidently the HPC does not necessarily recover the complete section at every deployment. On the other hand, it is clear that detailed biostratigraphy is extremely beneficial.

Finally, it may be of interest to note that the closer spaced sampling intervals in the study of JB revealed the presence of T. contortus in Hole 577, Core 9, Section 5, $30-115 \mathrm{~cm}$ (4 samples). Rare specimens of T. nunnii were also observed in the lowest of these samples. Since members of the genus Fasciculithus are abundant up to Sample 577-10-1, $30 \mathrm{~cm}$ and not present in Core 9, Section 6, we may conclude that the FO of $T$. contortus and the LO of Fasciculithus are separated by not less than $1.5 \mathrm{~m}$ of sediment, which in this case probably represents a period of time in excess of $0.2 \mathrm{~m}$.y. (this estimate is based on unpublished work by JB both from Site 577 and Leg 74 material).

\section{NEOGENE}

Two interrelated problems characterize the lowest part of the Neogene sequence (Fig. 3, Table 2). The first is that relatively large differences exist in numerical age estimates for two nannofossil datum levels when Hole 577 and Hole 577A are compared, and the other concerns whether the geomagnetic reversal succession is correctly identified. However, the succession of the nannofossil datum events agrees well with all available literature data: FO of Amaurolithus primus, LO of Discoaster quinqueramus, FO of Ceratolithus rugosus, LO of Amaurolithus tricorniculatus, and LO of Reticulofenestra pseudoumbilica.

Regarding interhole comparisons and age estimates of datum levels, two species are problematic: the FO level of $C$. rugosus and the LO level of $R$. pseudoumbilica. In both holes the LO level of the latter species occurs within the uppermost reversed magnetic interval of the Gilbert Epoch, but the relative positions within this reversed interval give age estimates that differ by approximately 0.3 m.y. Literature data (e.g., Backman and Shackleton, 1983) suggest that the age derived from Hole 577 (3.55 m.y.) represents a more consistent estimate for the $R$. pseudoumbilica extinction event, although our data do not reveal the cause for the older age estimate (3.87 m.y.) obtained from Hole 577A.

The FO level of $C$. rugosus is particularly troublesome since this marker level is associated with different geomagnetic events in the two holes and therefore causes an uncertainty as to the correct identification of the geomagnetic reversal sequence. A difference in age estimate of more than $0.2 \mathrm{~m}$.y. is evident, and our data do not reveal the cause for this discrepancy. 


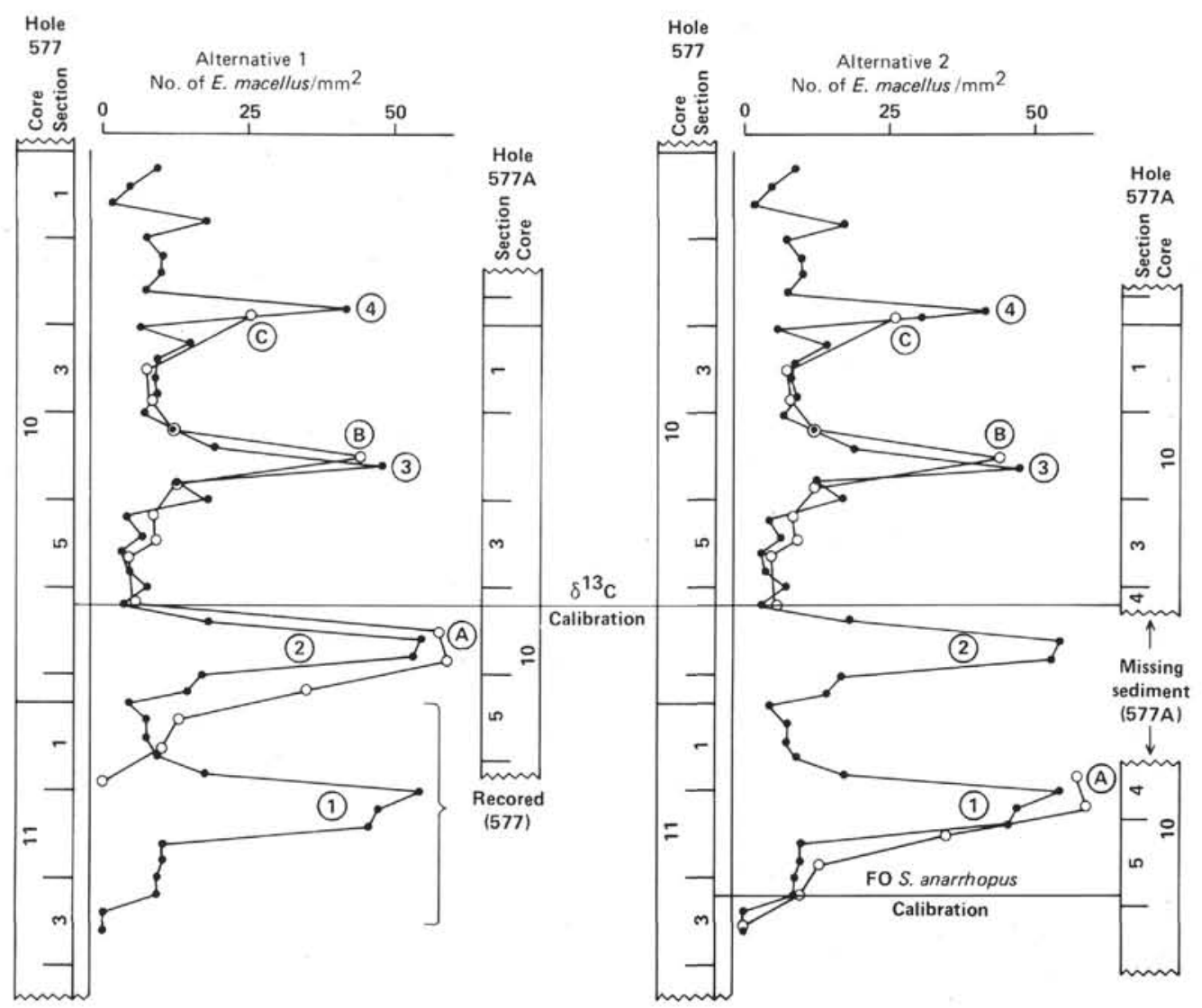

Figure 5. Plots of relative abundance variations of E. macellus in Holes $577(0)$ and 577A $(O)$. The $\delta^{13} \mathrm{C}$ calibration is from Shackleton (this volume) and the Sphenolithus anarrhopus calibration is from Backman (unpublished). See text for discussion of these results.

Previous data from the Pacific Ocean (Gartner, 1973; Backman and Shackleton, 1983) and from the South Atlantic (Hsü et al., 1984) unequivocally indicate that the FO level of $C$. rugosus occurs within the lowest normal event (Thvera) of the reversed Gilbert Epoch. Furthermore, according to literature data (Gartner, 1973; Hsü et al., 1984), the LO of D. quinqueramus occurs in mid-Epoch 5, within a reversed polarity event separating the two normals of this geomagnetic time unit. Our interpretation places the LO of $D$. quinqueramus higher in the geomagnetic reversal sequence (Fig. 3), in the lowest reversed interval of the Gilbert Epoch. Consequently, the interpretation of the lower Gilbert and Epoch 5 (Fig. 3) must be considered as tentative. Several other interpretations are possible and we would like briefly to discuss two of these, which may be regarded to be as tenable as the one shown in Figure 3.

If referring to Hole 577 and assuming that the FO level of $C$. rugosus is correct in this hole and associated with the Thvera Event, it follows (1) that the LO level of D. quinqueramus indeed has a position in mid-Epoch 5, in accord with literature data (see above) and (2) that our interpretation of the geomagnetic reversal sequences is erroneous.

If referring to Hole 577A and assuming that the FO level of C. rugosus is correct in this hole and associated with the Thvera Event, we can either conclude that the LO level of $D$. quinqueramus occurs stratigraphically higher than recorded from other areas, or that a hiatus encompassing the upper half of Epoch 5 and the lowest part of the Gilbert Epoch is present between the LO level of $D$. quinqueramus and the base of the Thvera Event.

There are quite a number of disturbed or unrecovered intervals in the uppermost parts of Holes 577 and 577A; however, only very minor inconsistencies in the correlations of nannofossil datum levels with the magnetostratigraphies are observed in the geomagnetic Gauss, Matuyama, and Brunhes epochs (Fig. 3, Table 2). Results obtained from the LO levels of Discoaster tamalis, $D$. pentaradiatus, $D$. brouweri, Calcidiscus macintyrei, and Emiliania ovata as well as for the FO of E. huxleyi are all in reasonable agreement with various data from the literature (Haq et al., 1977; Gartner, 1977; Backman and Shackleton, 1983; Hsü et al., 1984).

Because of the absence of generally accepted calcareous nannofossil criteria to correlate with geologic boundaries in the late Cenozoic, we have not discussed this topic in this chapter.

\section{CONCLUSIONS}

The magnetobiochronology derived from paleomagnetic and calcareous nannofossil stratigraphic analyses of sedimentary sequences recovered at Site 577 in the Northwest Pacific reveals a remarkable consistency with DSDP data sets from recent South Atlantic legs and with results obtained from marine sections in Italy. Cali- 
brated on the same geomagnetic polarity time scale deduced from oceanic anomaly lineations, the differences in numerical ages of individual nannofossil datum events are typically less than $0.5 \mathrm{~m}$.y. in the Late Cretaceous and Paleogene. Despite these positive correlations, the presently available data do not yet allow any conclusive interpretations in terms of global synchroneity or regional differentiations in evolutionary patterns for this period. Although the HPC technique has greatly improved the quality of materials retrieved by DSDP, the stratigraphic duplication in the adjacent holes at Site 577 still resulted in almost the same amount of mutual discrepancies in the two magnetobiochronologies as their comparison to distant areas in the South Atlantic or Mediterranean.

\section{ACKNOWLEDGMENTS}

We thank A. Wright, N. J. Shackleton, and W. A. Berggren for their constructive criticism. The financial support by the Deutsche Forschungsgemeinschaft (UB), by Naturvetenskapliga forskningsrådet (JB), and by CNR Centro Studi per la Geologia dell'Appennino e delle Catene Perimediterranee (Publ. 148) and MPI (SM) is gratefully acknowledged.

\section{REFERENCES}

Alvarez, W., Arthur, M. S., Fischer, A. F., Lowrie, W., Napoleone, G., Premoli-Silva, I., and Roggenthen, W. M., 1977. Type section for the Late Cretaceous-Paleocene geomagnetic reversal time scale. Geol. Soc. Am. Bull., 88:383-389.

Alvarez, W., and Lowrie, W., 1978. Upper Cretaceous paleomagnetic stratigraphy at Moria (Umbrian Apennines, Italy): Verification of the Gubbio section. Geophys. J. R. Astron. Soc., 55:1-17.

Backman, J., and Shackleton, N. J., 1983. Quantitative biochronology of Pliocene and early Pleistocene calcareous nannofossils from the Atlantic, Indian and Pacific oceans. Mar. Micropaleontol., 8: 141-170.

Berggren, W. A., Kent, D. V., and Flynn, J. J., in press. Paleogene geochronology and chronostratigraphy. In Snelling, N. J. (Ed.), Geochronology and the Geological Record. Spec. Publ. Geol. Soc. London.

Berggren, W. A., and Van Couvering, J. A., 1974. The Late Neogene. Palaeogeogr., Palaeoclimatol., Palaeoecol., 16:1-216.

Bukry, D., 1975. Coccolith and silicoflagellate stratigraphy, northwestern Pacific Ocean, Deep Sea Drilling Project Leg 32. In Larson, R. L., Moberly, R., et al., Init. Repts. DSDP, 32: Washington (U.S. Govt. Printing Office), 677-702.

Butler, R. F., Lindsay, E. H., Jacobs, L. L., and Johnson, N. M., 1977. Magnetostratigraphy of the Cretaceous-Tertiary boundary in the San Juan Basin, New Mexico. Nature (London), 267:318-323.

Foster, J. M., and Opdyke, N. D., 1970. Upper Miocene to Recent magnetic stratigraphy in deep-sea sediments. J. Geophys. Res., 75: $4465-4473$.

Gartner, S., 1973. Absolute chronology of the late Neogene calcareous nannofossil succession in the Equatorial Pacific. Geol. Soc. Am. Bull., 84:2021-2034.

, 1977. Calcareous nannofossil stratigraphy and revised zonation of the Pleistocene. Marine Micropaleontol., 2:1-25.

Haq, B. U., Berggren, W. A., and Van Couvering, J. A., 1977. Corrected age of the Pliocene/Pleistocene boundary. Nature (London), 269:483-488.
Hedberg, H. D., Salvador, A., and Opdyke, N. D., 1979. Magnetostratigraphic polarity units-A supplementary chapter of the ISSC International Stratigraphic Guide. Geology, 7:578-583.

Heirtzler, J. R., Dickson, G. O., Herron, E. M., Pitman, W. C., III, and LePichon, X., 1968. Marine magnetic anomalies, geomagnetic field reversals and motions of the ocean floor and continents. $J$. Geophys. Res., 73:2119-2136.

Hsü, K. J., He, Q., McKenzie, J. A., Weissert, H., Perch-Nielsen, K., Oberhänsli, H., Kelts, K., LaBrecque, J., Tauxe, L., Krähenbühl, U., Percival, S. F., Jr., Wright, R., Karpoff, A. M., Petersen, N., Tucker, P., Poore, R. Z., Gombos, A. M., Pisciotto, K., Carman, M. F., Jr., and Schreiber, E., 1982. Mass mortality and its environmental and evolutionary consequences. Science, 216:249-256.

Hsü, K. J., Percival, S. F., Wright, R. C., and Petersen, N., 1984. Numerical ages of magnetostratigraphically calibrated biostratigraphic zones. In Hsü, K. J., LaBrecque, J. L., et al., Init. Repts. DSDP, 73: Washington (U.S. Govt. Printing Office), 623-636.

LaBrecque, J., Kent, D. V., and Cande, S. C., 1977. Revised magnetic polarity time scale for Late Cretaceous and Cenozoic time. Geology, 5:330-335.

Lindsay E. H., Butler, R. F., and Johnson, N. M., 1981. Magnetic polarity zonation and biostratigraphy of Late Cretaceous and Paleocene continental deposits, San Juan Basin, New Mexico. Am. J. Sci., 282:390-435.

Lowrie, W., Alvarez, W., Napoleone, G., Perch-Nielsen, K., PremoliSilva, I., and Toumarkine, M., 1982. Paleogene magnetic stratigraphy in Umbrian pelagic carbonate rocks: The Contessa sections, Gubbio. Geol. Soc. Am. Bull., 93:414-432.

McDougall, I., 1977. The present status of the geomagnetic polarity time scale. Research School of Earth Sciences, A.N.U., Publ. No. 1288.

Monechi, S., 1977. Upper Cretaceous and Early Tertiary nannoplankton from the Scaglia Umbra Formation (Gubbio, Italy). Riv. Ital. Paleont., 83:759-802.

Monechi, S., and Thierstein, H. R., in press. Late Cretaceous-Paleogene nannofossil and magneto-stratigraphic correlation in the Umbrian Apennines. Mar. Micropaleontol.

Okada, H., and Bukry, D., 1980. Supplementary modification and introduction of code numbers to the low-latitude coccolith biostratigraphic zonation (Bukry, 1973, 1975). Mar. Micropaleontol., 5: 321-325.

Romein, A. J. T., 1979. Lineages in Early Paleogene calcareous nannoplankton. Utrecht Micropal. Bull., 22:1-231.

Shackleton, N. J. and Members of the Shipboard Scientific Party, 1984. Accumulation rates in Leg 74 sediments. In Moore, T. C., Jr., Rabinowitz, P. D., et al., Init. Repts. DSDP, 74: Washington (U.S. Govt. Printing Office), 621-644.

Tauxe, L., Tucker, P., Petersen, N. P., and LaBrecque, J. L., 1984. Magnetostratigraphy of Leg 73 sediments. In Hsü, K. J., LaBrecque, J. L., et al., Init. Repts. DSDP, 73: Washington (U.S. Govt. Printing Office), 609-621.

Theyer, F., and Hammond, S. R., 1974a. Cenozoic magnetic time scale in deep sea cores: Completion of the Neogene. Geology, 2: 487-492.

, 1974b. Paleomagnetic polarity sequence and radiolarian zones, Bruhnes to Epoch 20. Earth Planet. Sci. Lett., 22:307-319.

Thierstein, H. R., 1982. Terminal Cretaceous plankton extinctions: A critical assessment. Spec. Pap. Geol. Soc. Am., 190:385-399.

Date of Initial Receipt: 12 December 1983 Date of Acceptance: 20 July 1984 